УДК 581.1

\title{
Effect of Zinc Deficiency and Excess \\ on the Antioxidant Enzymes Activity \\ in Barley Seedling Leaves
}

\author{
Natalya M. Kaznina*, \\ Yulia V. Batova and Natalia S. Repkina \\ Institute of Biology Karelian Researches Centre RAS \\ Petrozavodsk, Russian Federation
}

Received 18.03.2021, received in revised form 11.05.2021, accepted 30.08.2021

\begin{abstract}
Zinc ( $\mathrm{Zn})$ is an essential microelement in plant nutrition but its high concentrations can be toxic to plants. Either $\mathrm{Zn}$ deficiency or its excess negatively affects plant metabolism, in particular due to alterations in cellular redox balance and development of oxidative stress. However, little is known about the effect of $\mathrm{Zn}$ deficiency and excess on the activity of antioxidant enzymes and expression of genes encoding them. The aim of this investigation was to study the effect of $\mathrm{Zn}$ deficiency and its excess on the intensity of oxidative processes, superoxide dismutase (SOD) and peroxidase (PO) activity, and genes ( $\mathrm{HvCu} / \mathrm{ZnSODI}$ and $\mathrm{HvPRX07)}$ expression in barley leaves (Hordeum vulgare L. cv. Nur). Plants were grown for 7 days at optimal zinc concentration $(2 \mu \mathrm{M})$, its deficiency $(0 \mu \mathrm{M})$ and excess $(1000 \mu \mathrm{M})$. Both stress factors caused similar shoot growth inhibition. However, they both differently influenced the intensity of lipid peroxidation (LPO), total enzyme activity and gene expression. $\mathrm{Zn}$ deficiency led to an increase in mRNA content of HvPRX07 gene, while the activities of PO and SOD were lower compared to those at optimal $\mathrm{Zn}$ level. The LPO intensity did not increase. $\mathrm{Zn}$ excess caused a significant increase in $\mathrm{HvCu} / \mathrm{ZnSOD1}$ gene expression, and the activity of both enzymes. LPO intensity also increased. This may suggest that under zinc deficiency the inhibition of plant growth is not directly related to the changes of cell redox balance, whereas $\mathrm{Zn}$ excess results in an oxidative stress that can cause inhibition of shoot growth.
\end{abstract}

Keywords: Hordeum vulgare L., zinc deficiency, zinc excess, antioxidant enzymes, genes expression.

Acknowledgements. The study was carried out under a state order (project No. 0218-2019-0074).

(C) Siberian Federal University. All rights reserved

This work is licensed under a Creative Commons Attribution-NonCommercial 4.0 International License (CC BY-NC 4.0).

* Corresponding author E-mail address: kaznina@krc.karelia.ru

ORCID: 0000-0003-3092-563X (Kaznina N.); 0000-0003-3804-8651 (Batova Y.); 0000-0002-8555-4701 (Repkina N.) 


\title{
Влияние дефицита и избытка цинка на активность антиоксидантных ферментов \\ В листьях ячменя
}

\author{
Н. М. Казнина, Ю. В. Батова, Н. С. Репкина \\ Институт биологии - обособленное подразделение ФГБУ \\ ИЦ «Карельский научный центр РАН» \\ Российская Федерация, Петрозаводск
}

\begin{abstract}
Аннотация. Цинк - один из наиболее важных микроэлементов для растений, но в высоких концентрациях он для них токсичен. Поэтому как недостаток металла, так и его избыток приводят к нарушению метаболизма растений, причиной которого может являться изменение редоксбаланса клеток и развитие в них окислительного стресса. Однако данных о влиянии дефицита и избытка цинка на активность компонентов антиоксидантной системы (АОС) относительно немного, а сведений об изменении в этих условиях экспрессии кодирующих их генов практически нет. Вследствие этого целью исследования явилось сравнительное изучение влияния дефицита и избытка цинка на интенсивность окислительных процессов, активность супероксиддисмутазы (СОД) и пероксидазы (ПО) и экспрессию генов HvCu/ZnSOD1 и HvPRX07 в листьях ячменя (Hordeum vulgare L.). Для этого растения выращивали в течение 7 сут в условиях контролируемой среды при оптимальной концентрации цинка (2 мкM), его недостатке (0 мкМ) или избытке (1000 мкМ). Обнаружено, что воздействие на проростки обоих стресс-факторов вызывало торможение роста побега, причем почти в равной степени. Однако их влияние на интенсивность перекисного окисления липидов (ПОЛ), общую активность ферментов и экспрессию генов оказалось различным. При дефиците цинка увеличивалось количество транскриптов гена $H v P R X 07$, но активность ПО и СОД была ниже, чем при оптимальном уровне металла. Это, однако, не приводило к усилению ПОЛ. При избытке цинка возрастала экспрессия гена $H v C u / Z n S O D 1$, увеличивалась активность СОД и ПО, но интенсивность ПОЛ при этом возрастала, свидетельствуя о развитии окислительного стресса. Полученные результаты показывают, что при дефиците цинка задержка роста растений не связана напрямую с нарушением окислительно-восстановительного баланса клеток, тогда как при его избытке (1000 мкМ) окислительный стресс является одной из причин ингибирования роста побега.
\end{abstract}

Ключевые слова: Hordeum vulgare L., дефицит цинка, избыток цинка, антиоксидантные ферменты, экспрессия генов.

Благодарности. Исследование выполнено при финансовой поддержке федерального бюджета в рамках выполнения государственного задания ИБ КарНЦ РАН (№ 0218-2019-0074). 
Цитирование: Казнина, Н. М. Влияние дефицита и избытка цинка на активность антиоксидантных ферментов в листьях ячменя / Н. М. Казнина, Ю. В. Батова, Н. С. Репкина // Журн. Сиб. федер. ун-та. Биология, 2021. 14(3). С. $287-295$. DOI: 10.17516/1997-1389-0351

\section{Introduction}

Micronutrient bioavailability is an important factor for normal growth, development and high productivity of plants. Zn plays a critical structural role in many proteins, including numerous transcription factors; it is also required as a cofactor in over 300 enzymes. However, excess of $\mathrm{Zn}$ can also be toxic to plants. Thus, both $\mathrm{Zn}$ deficiency and its excess destroy plant metabolism, inhibit growth and decrease plant productivity. Both stress conditions result in disturbance of cell redox balance and development of oxidative stress (Cakmak, 2000; Singh et al., 2016). Adaptation of plants to either zinc deficiency or zinc excess is mainly associated with the activity of the antioxidant system, including its enzyme components.

Previously, an increase of antioxidant enzymes activity under deficiency (Blasco et al., 2015; Tewari et al., 2019) and excess of zinc (Panda et al., 2003; Li et al., 2013) was reported. It typically corresponds with a decrease of oxidative stress and recovery of physiological processes. However, less is known about expression of genes encoding antioxidant enzymes under stress conditions. As well, few studies have compared the effects of zinc deficiency and its excess on the activity of the antioxidant system, especially in the case of almost identical plant response to these factors related to key physiological processes.

The aim of this study was to compare the effects of zinc deficiency and zinc excess in the growth medium on the intensity of oxidative processes, the activity of antioxidant enzymes and the expression of their encoding genes in barley seedling leaves.

\section{Materials and methods}

Seeds of barley (Hordeum vulgare L. cv. Nur) were surface sterilized and germinated on filter paper in the dark. One day after, seedlings were transferred to 1.0 L plastic pots with HoaglandArnon nutrient solution ( $\mathrm{pH} 6.2$ to 6.4) prepared using double-distilled water and high-purity reagents. A chemical analysis of nutrient solutions showed that $\mathrm{Zn}$ contamination was $\leq 0.05 \mu \mathrm{M}$, which is considered very low for plant growth. Seedlings were cultivated in a growth chamber under a 14-h photoperiod, a photosynthetic photon flux density of $180 \mu \mathrm{mol} \mathrm{m} \mathrm{m}^{-2} \mathrm{~s}^{-1}$, a temperature of $22{ }^{\circ} \mathrm{C}$ and relative humidity of $60-70 \%$ on nutrient solutions with optimal zinc content ( $\mathrm{Zn} 2$ $\mu \mathrm{M}$ - control), its deficiency ( $\mathrm{Zn} 0 \mu \mathrm{M})$ and excess ( $\mathrm{Zn} 1000 \mu \mathrm{M}$ ). Zinc was provided as $\mathrm{ZnSO}_{4}$. Concentrations of 2 and $1000 \mu \mathrm{M} Z n$ were chosen based on preliminary experiments as optimal and sublethal to this barley cultivar. No Zn was added to the solution to provide deficiency conditions ( $\mathrm{Zn}$ deficient medium). Sampling and measurements were performed on the 7th day of exposure with different $\mathrm{Zn}$ concentrations. The middle part of the lamina of a fully expanded first leaf was used for the analysis.

Malondialdehyde (MDA) content and antioxidant enzymes activity were determined on a spectrophotometer (Spectrum, Russia) using standard methods as we described earlier (Kaznina et al., 2018). To analyze MDA content, a reaction medium containing $0.25 \%$ solution of thiobarbituric acid (TBA) in $10 \%$ trichloroacetic acid was used. Plant material was homogenized in the reaction medium. The homogenate was aged in a water bath at $95{ }^{\circ} \mathrm{C}$ for 30 min, quickly cooled in an ice vessel and centrifuged for $10 \mathrm{~min}$ at 10,000 $\mathrm{g}$. The absorbance of the supernatant was measured 
at $\mathrm{D}=532$ and $600 \mathrm{~nm}$. The concentration of TBA-reacting products was calculated using the formula $\mathrm{C}_{\mathrm{MDA}}=\left(\mathrm{D}_{532}-\mathrm{D}_{600}\right) /(\varepsilon \times \mathrm{m})$, where $\mathrm{C}_{\mathrm{MDA}}$ is the concentration of MDA ( $\mu \mathrm{mol} \mathrm{g}^{-1}$ wet mass), $\mathrm{D}_{532}$ and $\mathrm{D}_{600}$ are optical densities of the sample at the appropriate wavelengths, $\varepsilon$ is the MDA extinction coefficient equal to $155 \mathrm{mmol}^{-1} \mathrm{~cm}^{-1}$, $\mathrm{m}$ is the mass of the sample $(\mathrm{g})$.

To determine the content of soluble proteins and the activity of antioxidant enzymes, plant material was homogenized in $0.1 \mathrm{M} \mathrm{K} / \mathrm{Na}-$ phosphate buffer $(\mathrm{pH}=7.8)$ at $2-4{ }^{\circ} \mathrm{C}$. The homogenate was centrifuged for 20 minutes at $15,000 \mathrm{~g}$ and $4{ }^{\circ} \mathrm{C}$. The supernatant was used for the analysis. Soluble protein content was determined by the Bradford method using bovine serum albumin as the standard.

Total activity of superoxide dismutase (SOD) (EC1.15.1.1) was determined based on the ability of SOD to inhibit photochemical reduction of nitrogen tetrazolium to formazan. The amount of the enzyme capable of suppressing the reduction of nitrogen tetrazolium by $50 \%$ was taken as a unit of SOD activity. Peroxidase (PO) activity (EC1.11.1.7) was measured by the increase in optical density at $470 \mathrm{~nm}$ resulting from guaiacol oxidation $\left(\mathrm{E}=26.6 \mathrm{mmol}^{-1} \mathrm{~cm}^{-1}\right)$ in the presence of hydrogen peroxide.

The expression pattern of $\mathrm{HvCu} / \mathrm{ZnSOD} 1$ and $H v P R X 07$ genes in leaves was monitored by a real-time PCR. Frozen leaf tissues were homogenized with liquid nitrogen. Total RNA was extracted using a TRizol reagent (Evrogen, Moscow, Russia) as instructed by the manufacturer. The total RNA was treated with RNase-free DNase (Syntol, Moscow, Russia) to remove genomic DNA. RNA concentrations and purity of the samples were determined spectrophotometrically (SmartSpecPlus, BioRad, Hercules, USA): samples with A260/A280 ratios within 1.8-2.0 were used for further analysis. The total RNA (1 $\mu \mathrm{g})$ was reversetranscribed using a MMLV RT kit (Evrogen) following the supplier's instructions. A realtime quantitative PCR was performed using the iCycler iQ detection system (Bio-Rad). Analyzes were performed using the SYBR Green PCR kit (Evrogen). The PCR conditions consisted in denaturation at $95{ }^{\circ} \mathrm{C}$ for $5 \mathrm{~min}$ followed by 45 cycles of denaturation at $95^{\circ} \mathrm{C}$ for $15 \mathrm{~s}$, annealing at $56{ }^{\circ} \mathrm{C}$ for $30 \mathrm{~s}$, and extension at $72{ }^{\circ} \mathrm{C}$ for $45 \mathrm{~s}$. A dissociation curve was generated at the end of each PCR cycle to verify that a single product was amplified using iCycler iQ. To minimize sample variations, mRNA expression of the target gene was normalized with respect to the expression of the housekeeping gene actin. The mRNA content of the target genes was quantified in comparison to the actin by the $\Delta \Delta \mathrm{Ct}$ method (Livak, Schmittgen, 2001). Primers were designed using the Primer Design program and are presented in Table 1.

Table 1. Primers for real-time PCR analysis

\begin{tabular}{|c|c|c|c|}
\hline Gene & Primers & Nucleotide sequence of the primer $5^{\prime}-3^{\prime}$ & NCBI database accession number \\
\hline \multirow{2}{*}{ HvActin } & direct & ATGTTTTTTTCCAGACG & \multirow{2}{*}{ U21907 } \\
\hline & reverse & ATCCAAGCCAACCCAAGT & \\
\hline \multirow{2}{*}{$\mathrm{HvCu/ZnSOD1}$} & direct & CCTGCCCTTTCCACTCG & \multirow{2}{*}{ HM537232 } \\
\hline & reverse & TGTCGTAGGACCGTCATCG & \\
\hline \multirow{2}{*}{$H v P R X 7$} & direct & TCCACCCTCATCTCCTCCTT & \multirow{2}{*}{ AJ003141 } \\
\hline & reverse & ACGGCTTGAACGGTCCTC & \\
\hline
\end{tabular}


The experiment was carried out using the equipment of the Core Facility in the Karelian Research Center of the Russian Academy of Sciences.

The experiment was conducted using a completely randomized design with 3 replications. The biological replication for different measurements within the control and each treatment group was from 3 to 10 plants, the analytical replication was 3-4-fold. All data are presented as mean \pm standard error (SE) from at least three independent replicates. The significance of differences between treatments was calculated by the two-way analysis of variance (ANOVA) using Microsoft Excel 2010. Student's $t$-test was applied to compare statistical significance at the level of $p<0.05$.

\section{Results}

Plants growth

The study showed that both zinc deficiency and its excess during 7 days equally slowed down seedling growth. For instance, in both treatment groups the shoot height was $15 \%$ less than in the control and dry biomass was $7 \%$ less than in the control (Table 2).

\section{MDA content}

Content of lipid oxidation products, in particular, MDA, is one of the most informative indicators of oxidative stress in the cell. We found that on the 7th day of plant growth under the conditions of zinc deficiency, there was no increase (as compared to control) in the MDA content in barley leaves, which indicates a low level of reactive oxygen species (ROS) in cells and absence of oxidative stress (Table 3). In contrast, under metal excess, the MDA amount significantly exceeded the control level, indicating an increase of lipid peroxidation intensity.

\section{Antioxidant enzyme activity}

We studied SOD, which participates in the superoxide radical detoxification, and PO, which eliminates excess hydrogen peroxide in cells, as

Table 2. The effect of zinc deficiency $(0 \mu \mathrm{M})$ and excess $(1000 \mu \mathrm{M})$ on barley (cv. Nur) shoot growth. Mean \pm $\mathrm{SE}, \mathrm{n}=10$

\begin{tabular}{lccc}
\hline \multirow{2}{*}{ Parameter } & \multicolumn{3}{c}{ Zinc concentration, $\mu \mathrm{M}$} \\
\cline { 2 - 4 } & Zn $2-$ control & Zn 0 & Zn 1000 \\
\hline Shoot height, cm & $18.95 \pm 0.25 \mathrm{~b}$ & $16.19 \pm 0.24 \mathrm{a}$ & $16.28 \pm 0.34 \mathrm{a}$ \\
Shoot dry biomass, mg & $20.37 \pm 0.50 \mathrm{~b}$ & $18.99 \pm 0.89 \mathrm{ab}$ & $18.99 \pm 0.45 \mathrm{a}$ \\
\hline
\end{tabular}

Note. Different letters denote significant differences at $\mathrm{p}<0.05$ within each row.

Table 3. The effect of zinc deficiency $(0 \mu \mathrm{M})$ and excess $(1000 \mu \mathrm{M})$ on malondialdehyde (MDA) content and superoxide dismutase (SOD) and peroxidase (PO) activity in barley (cv. Nur) leaves. Mean \pm SE $(n=4)$

\begin{tabular}{lccc}
\hline \multicolumn{1}{c}{ Parameter } & \multicolumn{3}{c}{ Zinc concentration, $\mu \mathrm{M}$} \\
\cline { 2 - 4 } & Zn 2 & Zn 0 & Zn 1000 \\
\hline MDA content, $\mu \mathrm{M} \mathrm{g}^{-1}$ f. w. & $2.17 \pm 0.10 \mathrm{~b}$ & $1.83 \pm 0.07 \mathrm{a}$ & $3.48 \pm 0.04 \mathrm{c}$ \\
SOD activity, conv. un. $\mathrm{mg}^{-1}$ protein & $2.95 \pm 0.28 \mathrm{~b}$ & $2.00 \pm 0.27 \mathrm{a}$ & $12.16 \pm 0.49 \mathrm{c}$ \\
PO activity, $\mu$ mol guaiacol $\mathrm{mg}^{-1}$ protein $\mathrm{min}^{-1}$ & $0.46 \pm 0.02 \mathrm{~b}$ & $0.34 \pm 0.03 \mathrm{a}$ & $2.35 \pm 0.15 \mathrm{c}$ \\
\hline
\end{tabular}

Note. Different letters denote significant differences at $\mathrm{p}<0.05$ within each row. 
key enzymes of antioxidant defense. The results showed that in seedlings growing under zinc deficiency the activity of both enzymes was lower than in the control (Table 3). In contrast, under zinc excess, SOD activity increased as compared to control by 4 times, PO activity increased by 5 times.

\section{The expression pattern of genes}

The experiments traced the dynamics of two genes transcripts: $H v C u / Z n S O D l$, encoding one of $\mathrm{Cu} / \mathrm{ZnSOD}$ isoforms in barley, which is involved in the response to abiotic and biotic stress (Abu-Romman, Shatnawi, 2011), and the PRXO7 gene, the expression of which in barley was previously identified only in response to biotic stress and injury (Kristensen et al., 1999).

The results indicated that after 7 days of seedling growth under zinc deficiency, the amount of $\mathrm{HvCu} / \mathrm{ZnSODl}$ gene transcripts in leaves remained at the control level, while the amount of HvPRX07 gene templates was almost 3 times higher (Figure). In contrast, under zinc excess, the mRNA content of $\mathrm{HvCu} / \mathrm{ZnSODI}$ gene increased notably (almost 5 times compared to the control), while no changes in the HvPRX07 gene expression were observed.

\section{Discussion}

Despite almost equal effect of zinc deficiency and its excess $(1000 \mu \mathrm{M})$ on barley shoot growth, these stress factors have different influence on the oxidative stress, the antioxidant enzymes activity, and their encoding genes expression.

\section{Zn deficiency}

The negative effect of zinc deficiency on the redox balance of plant cells is well known (Sharma et al., 2004; Wang, Jin, 2007; Blasco et al., 2015, etc). The authors conclude that it is largely due to a decrease in the activity of zinc-containing enzymes, for example, $\mathrm{Cu}$ / ZnSOD, which neutralizes the superoxide radical in cells. Zinc is also required for mannose-6-phosphate isomerase, a key lowmolecular-weight antioxidant in plant cells that is involved in the ascorbate metabolism (Höller et al., 2014).

In the present study, SOD activity was lower under zinc deficiency than in the control, although the level of $\mathrm{HvCu} / \mathrm{ZnSODI}$ gene expression did not change. It is possible to connect it with the decrease in the activity of the zinc-containing isoform $(\mathrm{Cu} / \mathrm{Zn} \mathrm{SOD})$, which is believed to make the greatest contribution to the overall enzyme activity (Kliebenstein et al., 1998; Naraikina

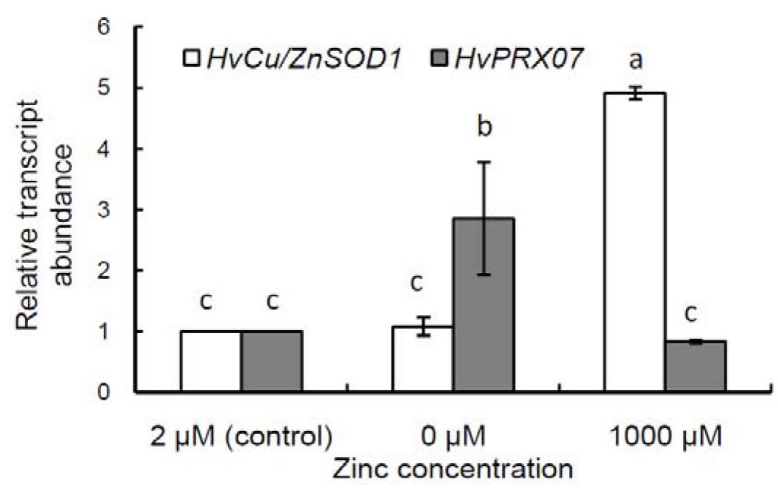

Figure. The effect of zinc deficiency $(0 \mu \mathrm{M})$ and excess $(1000 \mu \mathrm{M})$ on $H v C u / Z n S O D 1$ and $H v P R X 7$ genes transcription in barley (cv. Nur) leaves. Mean \pm SE $(n=3)$. Different letters denote significant differences at $p<0.05$ 
et al., 2014). A decrease in content of hydrogen peroxide produced by SOD could in turn be the cause of the observed decrease in PO activity, as hydrogen peroxide is the substrate for PO. The lower activity of enzymes involved in ROS elimination observed under such conditions could be also explained by occurring changes in physiological processes aimed at reducing the generation of oxygen radicals, for example, by a decrease in the photosynthetic rate (Mattiello et al., 2015).

It is interesting to note that no increase in total PO activity accompanied a significant increase in the amount of HvPRX07 gene transcripts under zinc deficiency (compared to the control). Possibly, at the initial stages of plant adaptation to a micronutrient deficiency, peroxidase encoded by this gene is involved in other processes, such as regulation of cell growth, lignification of cell walls or auxin metabolism (Cosio, Dunand, 2009).

Concerning the absence of MDA accumulation under zinc deficiency, it can be assumed that at the initial stages of growth seedlings could use the reserves of this trace element from the seed. Moreover, the maintenance of ROS balance under these conditions can be facilitated by an increase in the activity of other antioxidants that do not directly depend on zinc content. For example, a decrease in $\mathrm{Cu} / \mathrm{ZnSOD}$ activity under $\mathrm{Zn}$ deficiency can be partially compensated for by an increase in the activity of other SOD isoforms - Fe-SOD or Mn-SOD, which was shown by some authors (Tewari et al., 2008). In addition, some low molecular weight antioxidants can participate in the superoxide neutralization (Gill, Tuteja, 2010). For instance, under zinc deficiency, it is possible to switch the synthesis of ascorbic acid from the main pathway to an alternative one that does not require the participation of a Zn-containing enzyme (Höller et al., 2014).
Zn excess

Zinc, unlike copper and iron, does not participate in redox reactions, and its accumulation in cells cannot directly lead to an increase in ROS production (Blindauer, Schmid, 2010). However, high concentrations of this metal induce an indirect increase of oxidative stress (Panda et al., 2003; Singh et al., 2016). In this case, an increase in the activity of antioxidant enzymes and non-enzymatic compounds is also observed (Singh et al., 2016). In barley seedlings grown under zinc excess, a significant increase of MDA content was observed, indicating the development of oxidative stress. At the same time, SOD and PO activity increased. The observed lipid peroxidation (LPO) intensification in spite of SOD and PO activation may also be ascribed to exhaustion of the pool of lowmolecular antioxidants, for example, carotenoids and reduced glutathione. Glutathione is known to form complexes with heavy metals and is also consumed in the synthesis of phytochelatins (Barrameda-Medina et al., 2014; Bashmakova et al., 2016). It cannot also be excluded that under the stress induced by heavy metals LPO is stimulated through activation of lipoxygenase, the enzyme catalyzing this process (Remans et al., 2012; Liptáková et al., 2013; Barrameda-Medina et al., 2014).

Concerning gene expression, a sharp increase in the amount of $\mathrm{HvCu} / \mathrm{ZnSOD}$ gene transcripts was observed. Apparently, at the initial stages of plant adaptation to a zinc excess, $\mathrm{Cu} / \mathrm{ZnSOD}$ plays the main role in protecting leaf cells from the superoxide radical, and the increase in SOD activity in this case is likely to be largely associated with the synthesis of enzyme molecules de novo. The absence of an increase in the amount of HvPRX07 gene transcripts in response to zinc excess can be explained by the fact that the PO isoform encoded by this gene may not be involved in plant adaptation to this 
stress factor, and the increase in the total PO activity occurs at the expense of other isoforms.

\section{Conclusion}

In general, the impact of either zinc deficiency or zinc excess $(1000 \mu \mathrm{M})$ on barley seedlings within a 7-day period leads to a slowdown in shoot growth; and the effect is almost equal. At the same time, these stress factors influenced differently the intensity of oxidative processes in leaves, SOD and PO activity, and the expression of genes encoding them. Zinc deficiency did not cause an increase in the MDA content in leaves; therefore, inhibition of shoot growth in this treatment group was not associated with the development of oxidative stress in cells. A low activity of both antioxidant enzymes in this case, despite the increase in the mRNA content of HvPRX07 gene, suggests alternative mechanisms for maintaining the ROS balance in cells. In contrast, under zinc excess, the activity of SOD and PO increased, which corresponded with a sharp increase of $\mathrm{HvCu} / \mathrm{ZnSODl}$ gene expression. However, a rise in lipid peroxidation intensity observed in this case indicates a violation of pro-antioxidant balance and the development of oxidative stress, which could be one of the causes for shoot growth inhibition under this conditions.

\section{References}

Abu-Romman S., Shatnawi M. (2011) Isolation and expression analysis of chloroplastic copper/ zinc superoxide dismutase gene in barley. South African Journal of Botany, 77(2): 328-334

Barrameda-Medina Y., Montesinos-Pereira D., Romero L., Blasco B., Ruiz J. M. (2014) Role of GSH homeostasis under Zn toxicity in plants with different Zn tolerance. Plant Science, 227: 110-121

Bashmakova E. B., Pashkovskiy P.P., Radyukina N. L., Kuznetsov V. V. (2016) Interactive effects of zinc and nickel on the glutathione system state in Mimulus guttatus plants. Russian Journal of Plant Physiology, 63(5): 626-635

Blasco B., Graham N. S., Broadley M. R. (2015) Antioxidant response and carboxylate metabolism in Brassica rapa exposed to different external $\mathrm{Zn}, \mathrm{Ca}$ and Mg supply. Journal of Plant Physiology, 176: $16-24$

Blindauer C.A., Schmid R. (2010) Cytosolic metal handling in plants: determinants for zinc specificity in metal transporters and metallothioneins. Metallomics, 2(8): 510-529

Cakmak I. (2000) Possible roles of zinc in protecting plant cells from damage by reactive oxygen species. New Phytologist, 146(2): 185-205

Cosio C., Dunand C. (2009) Specific functions of individual class III peroxidase genes. Journal of Experimental Botany, 60(2): 391-408

Gill S.S., Tuteja N. (2010) Reactive oxygen species and antioxidant machinery in abiotic stress tolerance in crop plants. Plant Physiology and Biochemistry, 48(12): 909-930

Höller S., Hajirezaei M.-R., von Wirén N., Frei M. (2014) Ascorbate metabolism in rice genotypes differing in zinc efficiency. Planta, 239(2): 367-379

Kaznina N., Batova Y., Repkina N., Laidinen G., Titov A. (2018) Cadmium treatment effects on the growth and antioxidant system in barley plants under optimal and low temperature. Acta Agriculturae Slovenica, 111(1): 169-176

Kliebenstein D. J., Monde R.-A., Last R.L. (1998) Superoxide dismutase in Arabidopsis: an eclectic enzyme family with disparate regulation and protein localization. Plant Physiology, 118(2): $637-650$ 
Kristensen B. K., Bloch H., Rasmussen S. K. (1999) Barley coleoptile peroxidases. Purification, molecular cloning and induction by pathogens. Plant Physiology, 120(2): 501-512

Li X., Yang Y., Jia L., Chen H., Wei X. (2013) Zinc-induced oxidative damage, antioxidant enzyme response and proline metabolism in roots and leaves of wheat plants. Ecotoxicology and Environmental Safety, 89: 150-157

Liptáková L., Huttová J., Mistrík I., Tamás L. (2013) Enhanced lipoxygenase activity is involved in the stress response but not in the harmful lipid peroxidation and cell death of short-term cadmiumtreated barley root tip. Journal of Plant Physiology, 170(7): 646-652

Livak K. J., Schmittgen T.D. (2001) Analysis of relative gene expression data using real-time quantitative PCR and the $2-\Delta \Delta$ Ct method. Methods, 25(4): 402-408

Mattiello E. M., Ruiz H. A., Neves J.C.L., Ventrella M.C., Araujo W.L. (2015) Zinc deficiency affects physiological and anatomical characteristics in maize leaves. Journal of Plant Physiology, 183: $138-143$

Naraikina N. V., Sin'kevich M.S., Demin I. N., Selivanov A. A., Moshkov I. E., Trunova T. I. (2014) Changes in the activity of superoxide dismutase isoforms in the course of low-temperature adaptation in potato plants of wild type and transformed with $\Delta 12$-acyl-lipid desaturase gene. Russian Journal of Plant Physiology, 61(3): 332-338

Panda S. K., Chaudhury I., Khan M.H. (2003) Heavy metals induce lipid peroxidation and affect antioxidants in wheat leaves. Biologia Plantarum, 46(2): 289-294

Remans T., Opdenakker K., Guisez Y., Carleer R., Schat H., Vangronsveld J., Cuypers A. (2012) Exposure of Arabidopsis thaliana to excess Zn reveals Zn-specific oxidative stress signature. Environmental and Experimental Botany, 84: 61-71

Sharma P.N., Kumar P., Tewari R.K. (2004) Early signs of oxidative stress in wheat plants subjected to zinc deficiency. Journal of Plant Nutrition, 27(3): 451-463

Singh S., Parihar P., Singh R., Singh V.P., Prasad S. M. (2016) Heavy metal tolerance in plants: role of transcriptomics, proteomics, metabolomics, and ionomics. Frontiers in Plant Science, 6: 1143

Tewari R.K., Kumar P., Sharma P.N. (2008) Morphology and physiology of zinc-stressed mulberry plants. Journal of Plant Nutrition and Soil Science, 171(2): 286-294

Tewari R. K., Kumar P., Sharma P.N. (2019) An effective antioxidant defense provides protection against zinc deficiency-induced oxidative stress in Zn-efficient maize plants. Journal of Plant Nutrition and Soil Science, 182(5): 701-707

Wang H., Jin J. (2007) Effects of zinc deficiency and drought on plant growth and metabolism of reactive oxygen species in maize (Zea mays L.). Agricultural Sciences in China, 6(8): 988-995 